Universidade de Brasília

Faculdade de Economia, Administração, Contabilidade e Ciências da Informação e Documentação

Daniela Kruel Rodrigues

\title{
DISCURSO ORGANIZACIONAL EM GESTÃO DE PESSOAS: Um estudo sobre as implicações do discurso da organização na vida de seus funcionários
}


Universidade de Brasília

Faculdade de Economia, Administração, Contabilidade e Ciências da Informação e Documentação

\section{DISCURSO ORGANIZACIONAL EM GESTÃO DE PESSOAS: Um estudo sobre as implicações do discurso da organização na vida de seus funcionários}

Trabalho de Conclusão de Curso apresentado ao Departamento de Administração como requisito parcial à obtenção do título de Bacharel em Administração.

Professor Orientador: Prof. Dr. Marcus Vinicius Soares Siqueira

$$
\text { Brasília - DF }
$$

Dezembro / 2009 
Rodrigues, Daniela Kruel.

Discurso Organizacional em Gestão de Pessoas: Um estudo sobre as implicações do discurso da organização na vida de seus funcionários / Daniela Kruel Rodrigues. - Brasília, 2009. $50 \mathrm{f}$.

Monografia (bacharelado) - Universidade de Brasília, Departamento de Administração, 2009.

Orientador: Prof. Dr. Marcus Vinicius Soares Siqueira, Departamento de Administração.

1. Discurso Organizacional. 2. Controle Organizacional. 3. Relações de Trabalho. I. Título: Subtítulo. 


\title{
DISCURSO ORGANIZACIONAL EM GESTÃO DE PESSOAS: Um estudo sobre as implicações do discurso da organização na vida de seus funcionários
}

A Comissão Examinadora, abaixo identificada, aprova o Trabalho de Conclusão do Curso de Administração da Universidade de Brasília da aluna

\section{Daniela Kruel Rodrigues}

\author{
Prof. Dr. Marcus Vinicius Soares Siqueira \\ Professor-Orientador
}

Prof. Dr. Pedro Paulo Murce Meneses

Professor-Examinador
Prof. Marcelo Magno Rocha

Nascimento

Professor-Examinador 
Ao meu querido avô Carlos. Que Deus o abençoe! 
Agradeço aos meus pais, pela dedicação e amor incondicional. A Deus, que sempre esteve ao meu lado, me guiando e protegendo. Aos meus avós, pessoas excepcionais que sempre me proporcionaram momentos de muita alegria e aprendizado. Ao meu namorado e sua família, pelo apoio e amizade. Obrigada a todos! 


\section{RESUMO}

Esta pesquisa identifica de que maneira os funcionários de uma empresa privada são influenciados pelo discurso organizacional em Gestão de Pessoas e de que forma eles reagem a esta influência: quais as representações existentes no discurso organizacional da empresa, quais as representações dos próprios funcionários, de que forma o discurso organizacional se insere na dinâmica de trabalho da empresa e de que forma os funcionários reagem aos esforços da organização em tentar seduzi-los. Fundamentada nos conceitos de sedução, fascínio, servidão voluntária e controle organizacional, a pesquisa contribui para desvelar as relações de poder que permeiam o discurso organizacional, que tentam instrumentalizar o indivíduo e justificar determinadas práticas organizacionais. Para isso, foi realizado um estudo descritivo. Os dados foram coletados pelo método qualitativo, por meio de entrevistas semi-estruturadas com seis funcionários de uma multinacional asiática, das áreas de pré-venda e pós-venda, que foram submetidas, posteriormente, à análise de conteúdo. Como resultado da pesquisa, foi identificado de que maneira os funcionários da empresa são influenciados pelo discurso organizacional e de que forma eles reagem a esta influência por meio de seis categoriais complementares: o desafio cultural, as peculiaridades do ambiente de trabalho, a difícil rotina de trabalho, os mecanismos asiáticos de controle organizacional, comprometimento só até certo ponto e planejando o futuro. As principais conclusões foram que os funcionários demonstram ter uma grande conscientização sobre o que representam para a empresa e, por causa disso, apresentam uma postura ativa para defender seus desejos perante as imposições organizacionais, se sujeitando ao discurso até o ponto que considerarem ser seus limites físicos e emocionais.

$\begin{array}{lll}\text { 1. Discurso Organizacional } & \text { 2. Controle Organizacional } & \text { 3. Relações de Trabalho }\end{array}$ 


\section{SUMÁRIO}

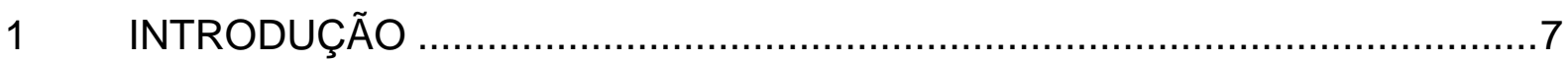

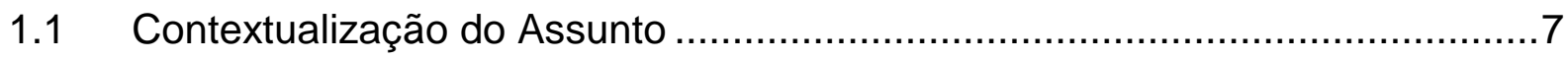

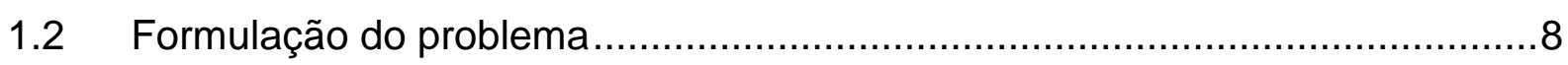

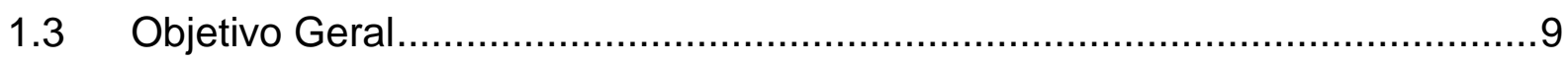

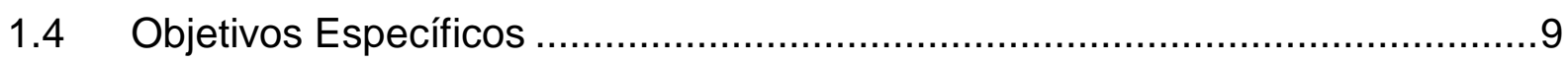

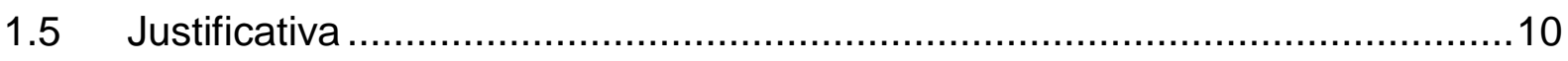

1.6 Métodos e Técnicas de Pesquisa:..........................................................10

1.7 Estrutura e Organização da Monografia ..................................................11

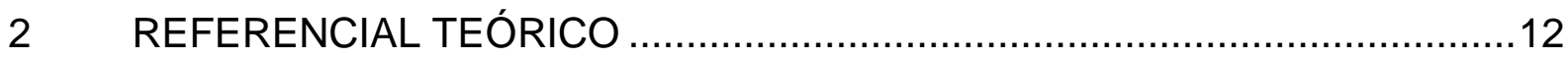

2.1 Contextualização das Relações de Trabalho ...........................................12

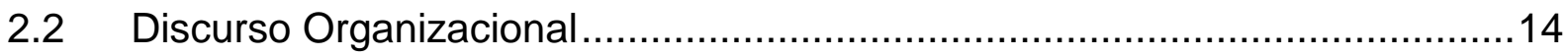

2.3 Controle nas Organizações ..................................................................17

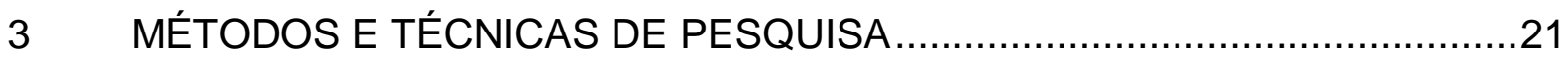

3.1 Tipo e descrição geral da pesquisa .........................................................

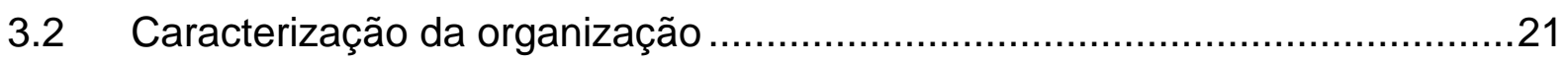

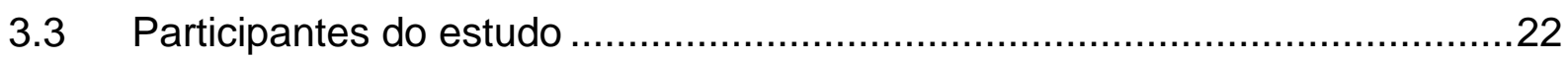

3.4 Caracterização do instrumento de pesquisa...............................................23

3.5 Procedimentos de coleta e de análise de dados ........................................24

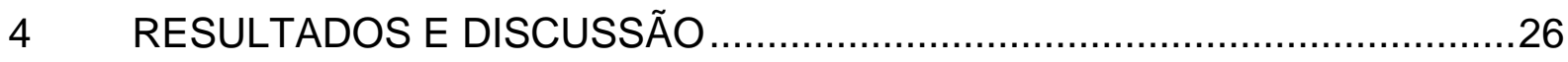

5 CONCLUSÕES E RECOMEDAÇÕES ………...................................... 44

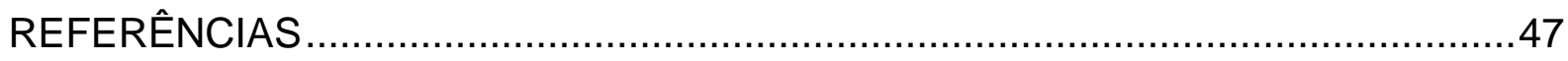

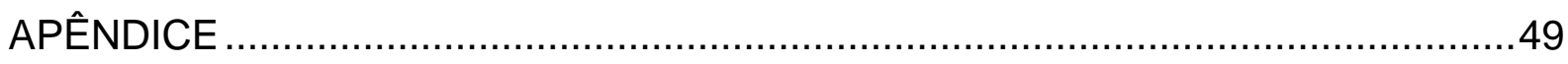

Apêndice A: Roteiro de Entrevista.................................................................... 


\section{INTRODUÇÃO}

Quem ainda tem uma alma hoje? Premiados pelo estresse, impacientes para ganhar e gastar, para fruir e morrer, os homens e mulheres de hoje fazem a economia dessa representação de sua experiência daquilo que chamamos de vida psíquica. Não se tem nem tempo nem espaço para fazer uma alma para si. Voltado para o próprio umbigo sobre seu quanto-a-simesmo, o homem moderno é um narcisista, talvez sofredor, mas sem remorsos (KRISTEVA apud GAULEJAC, 2007, p.177).

Essa declaração, da filósofa Julia Kristeva, é bastante pertinente para o objeto de estudo desta pesquisa, na medida em que ilustra o indivíduo moderno e suas preocupações.

Segundo Siqueira (2007), essa nova maneira de ser e agir do ser humano é uma conseqüência do contexto social e organizacional no qual este está inserido. Para compreender de que forma esse processo de influência ocorre, é necessário analisar a organização mais a fundo, isto é, entender o que está por trás de seu discurso e quais as implicações desse discurso na saúde física e psíquica do trabalhador.

É com base nesta temática que este estudo foi desenvolvido.

\subsection{Contextualização do Assunto}

A crescente competição e a complexidade das empresas atuais têm exigido novas justificativas e estudos visando o realinhamento do capitalismo global (FREITAS, 2002). Nessas organizações, o desgaste da mente e do corpo do trabalhador tem se tornado freqüente (ARAÚJO, 2008). Trabalhar em um ambiente como esse afeta, direta ou indiretamente, o trabalhador desde o seu nível individual até o do social mais amplo (FREITAS, 2000). E é diante desta realidade e ambiente que esta pesquisa se estruturou.

O discurso organizacional em Gestão de Pessoas atual é impregnado de conceitos como o de sedução, fascínio e servidão voluntária. Sendo assim, compreender de que forma o trabalhador se relaciona com este discurso torna-se fundamental para esta temática, pois só assim será possível: 
conhecer um pouco mais sobre as organizações atuais, e, especialmente, sobre as empresas, que ocupam lugar de destaque no contexto contemporâneo, na construção social da realidade, no desenvolvimento socioeconômico e na definição do atual sistema político mundial (SIQUEIRA, 2009, p.17).

Além disso, Siqueira (2009) destaca a importância de se entender o discurso organizacional de forma ideológica, pois, além de seu aspecto funcional, esse tipo de discurso contribui para a construção de identidades e das relações sociais entre os indivíduos.

Ou seja, de acordo com o autor, é necessário captar o que existe por trás do discurso organizacional: no sentido de controle do indivíduo e a forma como a organização usa o seu discurso e a sua cultura para conquistar e atrair o trabalhador, para que este possa alcançar os objetivos organizacionais (SIQUEIRA, 2009).

\subsection{Formulação do problema}

De acordo com Enriquez (2002), com o passar dos anos o individualismo tem ganhado cada vez mais força e, conseqüentemente, o ser humano tem se libertado do coletivismo ao qual ele estava até então vinculado. Com isso, o indivíduo passou a ir à conquista de si próprio, dos outros e de seus sonhos.

Entretanto, é nesse cenário de libertação que se encontra a grande armadilha. Para o autor, nunca o indivíduo esteve tão preso à organização como ele é hoje, sem domínio de seu corpo e de sua psique.

Esse controle só é possível porque o indivíduo se deixa levar, seja direta ou indiretamente, consciente ou inconscientemente, pelo discurso pregado pela organização, que oferece a possibilidade de sucesso e realização em troca da submissão do trabalhador a seu discurso (SIQUEIRA, 2009).

É nesse contexto que surgiu a necessidade de verificar de que forma o discurso organizacional pode influenciar os funcionários de uma empresa privada. Ou seja, de que forma esse discurso em Gestão de Pessoas influencia a subjetividade do indivíduo, moldando seu comportamento de acordo com as necessidades organizacionais. 


\subsection{Objetivo Geral}

No intuito de alcançar esse propósito, e utilizando uma abordagem crítica, esta pesquisa teve como objetivo identificar de que maneira os funcionários de uma empresa privada são influenciados pelo discurso organizacional em Gestão de Pessoas e de que forma eles reagem a essa influência.

\subsection{Objetivos Específicos}

Tendo em mente o objetivo geral desta pesquisa, procurou-se, durante a entrevista:

- Identificar as representações existentes no discurso organizacional da empresa;

- Identificar as representações dos próprios funcionários;

- Avaliar de que forma o discurso organizacional se insere na dinâmica de trabalho da empresa analisada;

- Analisar de que forma os funcionários reagem aos esforços da organização para tentar seduzi-los em prol do discurso organizacional.

Para alcançar este propósito, serão considerados aspectos da dinâmica de trabalho dos indivíduos entrevistados, como: adesão/apoio ao discurso organizacional, rotina de trabalho e o tempo dedicado a este, se seus desejos e interesses profissionais estão alinhados aos objetivos organizacionais e de que forma o trabalho afeta seus planos de vida, no âmbito pessoal e profissional.

Ou seja, pode-se dizer que esta pesquisa teve como foco tentar investigar, de forma geral, a psique humana: saber como ela percebe e reage ao discurso organizacional moderno. 


\subsection{Justificativa}

A partir do momento que se conhece a forma na qual a organização se estrutura e como manifesta o seu poder, o trabalhador passa a enxergar o seu meio de trabalho de forma mais crítica e conscientizada, podendo, assim, ter uma postura mais ativa, mesmo que ainda parcial, para defender seus interesses e desejos.

Assim sendo, esta pesquisa pretendeu contribuir para desvelar as relações de poder que permeiam o discurso organizacional, que tentam instrumentalizar o indivíduo e justificar determinadas práticas.

Essas relações de poder, influenciadoras do discurso organizacional, passam uma visão parcial da realidade. A empresa defende o ideal de que para aqueles que "estiverem dispostos a fazer renúncias em prol de seus objetivos, ela vai atendê-los em suas necessidades e desejos pessoais, especialmente em termos de poder e cargos" (SIQUEIRA, 2009, p.21). No entanto, a organização omite a degradação do vínculo social, a competição, as práticas desleais, a exclusão daqueles que não se adaptam a este modelo, dentre outras ações. E é justamente esse outro lado que esta pesquisa pretende revelar, mostrando o impacto dessas conseqüências para a vida de seus funcionários.

Do ponto de vista acadêmico, esta pesquisa teve como intenção ilustrar de que forma esta temática se dá na prática, mostrando a importância deste assunto para compreensão das relações organizacionais atuais, bem como estimulando novas pesquisas na área.

\subsection{Métodos e Técnicas de Pesquisa}

Esta pesquisa teve o objetivo de identificar de que forma o discurso organizacional da empresa é percebido pelo indivíduo e como este reage a esse discurso. Para isso, foi realizado um estudo descritivo, utilizando uma abordagem crítica.

Os dados foram coletados pelo método qualitativo, por meio de uma entrevista guiada, com base em um roteiro semi-estruturado desenvolvido para tal 
fim. Essas entrevistas, realizadas com seis profissionais da área comercial de uma multinacional asiática, foram individuais e conduzidas pela própria pesquisadora. $\mathrm{O}$ horário e local das entrevistas foram definidos pelos próprios entrevistados. Posteriormente, os dados obtidos com as entrevistas passaram pelo processo de análise de conteúdo.

\subsection{Estrutura e Organização da Monografia}

Além da Introdução, este estudo foi dividido em mais quatro capítulos, descritos a seguir.

$\mathrm{Na}$ primeira seção, encontra-se o Referencial Teórico. Este capítulo foi dividido em três temas fundamentais para a compreensão desta pesquisa: Relações de Trabalho, Discurso Organizacional e Controle Organizacional.

O próximo capítulo, Métodos e Técnicas de Pesquisa, aborda a metodologia empregada para realizar a pesquisa propriamente dita. Nesta seção se caracterizam a pesquisa, os sujeitos participantes, a empresa estudada, o instrumento de pesquisa e a forma no qual os dados foram coletados e analisados.

A seguir, apresenta-se o capítulo de Resultados e Discussão. É nesta seção que foram expostas, por meio da criação de seis categorias, as percepções dos funcionários a respeito do discurso da empresa e a forma no qual esse discurso afeta sua vida pessoal e profissional.

Por fim, o capítulo, Conclusões e Recomendações, reforça as conclusões obtidas na seção de resultados, relata as limitações, bem como faz sugestões para próximas pesquisas. 


\section{REFERENCIAL TEÓRICO}

Neste capítulo serão tratados assuntos que são de extrema relevância para a compreensão do tema desta pesquisa, bem como de seu objetivo. Para isso, este capítulo foi dividido em três partes essenciais.

A primeira parte pretende contextualizar as relações de trabalho, analisando de que forma estas relações têm se apresentado ao longo dos anos e as mudanças que têm sofrido durante esse período. Pretende-se com este tópico tentar explicar, em linhas gerais, de que forma as relações de trabalho contribuem para a adesão dos trabalhadores ao discurso pregado pelas organizações.

Já a segunda parte deste capítulo abordará o discurso organizacional em si, conceituando-o e caracterizando sua esfera ideológica. A partir do momento que se entende o que é o discurso e de que forma ele ocorre, consegue-se entender o motivo pelo qual este é utilizado como uma forma de seduzir e controlar os indivíduos.

Finalmente, a última parte desta seção tratará do assunto foco desta pesquisa, isto é, o controle organizacional. É nesse momento que serão tratadas as formas na qual a organização tenta exercer controle sob o indivíduo, os mecanismos que ela utiliza para isso, bem como as conseqüências que isso gera na vida profissional e pessoal de seus funcionários.

\subsection{Contextualização das Relações de Trabalho}

Desde o século $X X$, a sociedade ocidental já apresentava um cenário marcado pelas grandes transformações sociais, políticas e econômicas, bem como pelo seu intenso desenvolvimento tecnológico. Um século depois, percebe-se que essa realidade não só continua, mas tem se tornado cada vez mais acentuada. E é nesse contexto que as empresas ganham poder e surgem como grandes influenciadoras na política, na economia e na vida social (SIQUEIRA, 2009).

Em conseqüência desse novo papel das empresas, a partir da década de 1980, os estudos na área de Administração passaram a incluir outros campos de 
conhecimento, como o da psicologia e o da antropologia (FARIA, 2007). Com isso, tem-se dado valor não só ao racional, mas também ao subjetivo:

surgem, aí, continuamente novos tipos de relações de trabalho e de estilos de vida. A sociedade atual parece assumir características voltadas ao desenvolvimento tecnológico e tudo o que ele acarreta, como as redes de informação e a biotecnologia. O indivíduo é obrigado a se inserir nessa realidade criada pelo progresso, adaptando-se de modo a alcançar 0 atendimento de seus desejos (SIQUEIRA, 2009, p.27).

A noção de trabalho também sofreu algumas mudanças ao longo dos tempos. A partir do século XVIII, tentou-se atribuir à idéia de trabalho uma dignidade negada pelos séculos anteriores. $O$ trabalho passou a ser reconhecido como um valor em si mesmo e não unicamente como uma necessidade ou imposição; sem o trabalho nenhum indivíduo conseguiria viver dignamente. Por menor que fosse seu impacto na mudança da realidade, essas alterações já sinalizavam um progresso (ARAÚJO, 2008).

Ainda de acordo com o autor, também muitos foram os feitos para se tentar humanizar o trabalho. Antes do capitalismo, os senhores já davam "mimos" materiais ou simbólicos aos seus subordinados como forma de seduzi-los, fingindo que os valorizavam. Outra iniciativa foram os estudos de Elton Mayo na Western Electric Company, na segunda metade da década de 1920. Mayo fez da psicologia um instrumento de capital: atribuiu os problemas organizacionais a causas "metassociais" para preservar a empresa de críticas. Apesar de suas falhas e conclusões parciais da realidade, o estudo de Mayo contribuiu para o surgimento da escola das "Relações Humanas", uma adaptação da psicologia para o campo da administração.

Mesmo com todos esses esforços, essas transformações não acabaram com a distância entre o trabalho idealizado - como fonte de realização pessoal - e o trabalho imposto, fonte de dor e sofrimento. Esse fato não só é verdade, mas também é mostrado diariamente pelos canais de comunicação, que retratam a dura realidade de muitos trabalhadores, em contraposição ao glamour vivido por poucos profissionais (ARAÚJO, 2008).

Frente a essa realidade, percebe-se uma contradição entre o discurso das empresas teoricamente avançadas e a forma com que o trabalho se dá nelas. Notase cada vez mais que o desgaste físico e psíquico no trabalho tem se tornado uma espécie de regra dos modelos de gestão de empresas públicas e privadas (ARAÚJO, 2008). E é nesse contexto que o indivíduo e a sua psique ganham 
destaque e o seu envolvimento é considerado como uma premissa para se alcançar o sucesso da organização (SIQUEIRA, 2009).

Ainda de acordo com Siqueira (2009), as empresas investem alto em treinamentos, buscando a interiorização dos valores e objetivos organizacionais, a fim de ter seus funcionários comprometidos e atingir seus resultados financeiros.

Por conta de seus inúmeros esforços para "conquistar" esses trabalhadores, as organizações modernas assumiram uma importância na vida dos indivíduos nunca vista antes; a forma como as relações de trabalho se dá monopoliza a vida social dos sujeitos, e estes vínculos, mais estreitos do que nunca, ultrapassam a relação com o próprio trabalho. Por sua vez, os indivíduos se ligam à organização, por meio de laços materiais, afetivos, imaginários e psicológicos (FREITAS, 2002). A empresa é "personificada" e, em troca de sua devoção, o trabalhador espera dela reconhecimento e amor (GAULEJAC, 2007).

Não obstante, é importante salientar a importância do discurso organizacional nesse contexto, já que este tem um papel essencial no processo de conquista do trabalhador, além de influenciar as relações de trabalho. É sobre esse assunto que o próximo tópico abordará a respeito.

\subsection{Discurso Organizacional}

O discurso é fundamental no ambiente organizacional e está presente em todas as esferas da vida social. Ele possui uma rede simbólica de relações de domínio e poder, que monitora cada palavra expressa no ambiente organizacional (FARIA, 2007). O discurso pode ser conceituado como:

uma manifestação concreta que um sujeito individual ou coletivo faz, por
meio da linguagem, na qual expressa não somente uma racionalidade
histórica e social, mas também processos inconscientes que movem os
desejos, as pulsões e os mecanismos de defesa, através da materialização
das palavras, as quais ao mesmo tempo em que estabelecem padrões e
criam moldes que devem ser adotados pelos sujeitos sociais na tentativa se
enquadrar socialmente, conformam-se a esses moldes (FARIA, 2007,
p.125).

Nas organizações atuais, o discurso é monitorado através do diálogo individual e dos grupos que compõem a rede de relacionamento da organização. Para que este possa ser legitimado, o seu locutor deverá carregar toda a carga 
simbólica que é aceita pelo grupo. O seu conteúdo deve estar de acordo com a postura do indivíduo e a linguagem da autoridade só será aceita quando os seus subordinados aceitarem suas condições e a cumprirem como regra (FARIA, 2007).

Tendo isso em mente, passa-se a analisar o discurso ideológico propriamente dito, ou seja, aquele discurso que está impregnado por ideais, sonhos e promessas. Um discurso pregado por um grupo dominante, portador de mecanismos de controle social, para conquistar os demais grupos e impor suas concepções sobre eles (FARIA, 2007).

De acordo com Siqueira (2007), esse discurso organizacional tem como finalidade dominar a psique do indivíduo, permitindo assim que a empresa tenha funcionários realmente comprometidos com a organização.

É importante ressaltar que as organizações não buscam qualquer indivíduo, mas sim aqueles "winners que têm gosto pelo desempenho e pelo sucesso, que estão prontos para se devotar de corpo e alma" (GAULEJAC, 2007, p.116). Ou seja, já se seleciona pessoas que possuem características ou indícios favoráveis à sedução organizacional.

Segundo Enriquez (2002), as empresas têm a tendência de escolher pessoas cujos comportamentos estão alinhados com o estilo da organização. Quando estas não o são, a empresa as transformará em indivíduos que apresentem, mesmo que só externamente, algumas qualidades que contribuam para o sucesso da organização.

É por meio do trabalho realizado, da pressão exercida pelo grupo, pela ideologia da empresa, pelos estágios de formação no qual o indivíduo passa que a empresa consegue realizar essa transformação no funcionário novo. Os processos, a dinâmica de trabalho, as pessoas: tudo reflete o modo de pensar da organização (ENRIQUEZ, 2002). A partir do momento que um novo indivíduo se insere nessa realidade organizacional, é uma questão de tempo para que ele se transforme e passe a ser um reflexo da empresa. A mudança, nesse momento, passa a ser um processo natural dentro da vida organizacional.

Esse indivíduo "deixa-se conduzir pelo imaginário organizacional moderno, e se coloca em uma posição de super-herói, de trabalhador incansável, de atleta corporativo, acreditando nas promessas da organização" (SIQUEIRA, 2007, p.5). 
A razão pela qual esse indivíduo adere a esse discurso é porque ele acredita que, fazendo parte do grupo dos detentores do poder, ele conseguirá ser reconhecido e, com isso, alcançar o seu ideal de ego (SIQUEIRA, 2009).

É diante desse cenário que ganham força principalmente duas categorias do discurso organizacional de Siqueira (2009): o superexecutivo de sucesso e o comprometimento organizacional, dois focos almejados pelas organizações. Sobre a primeira categoria, Siqueira:

enquadra basicamente dois critérios fundamentais: o sucesso, e tudo aquilo
que os indivíduos estão dispostos a fazer para alcançá-lo, e o perfil do
super-homem: toda organização deseja ter em seus quadros executivos que
sejam verdadeiros super-homens, isto é, eternos conquistadores de
territórios/mercado (SIQUEIRA, 2009, p.119).

Já a categoria do comprometimento organizacional está ligada a idéia do indivíduo ter seus objetivos e valores alinhados com os da organização. $\mathrm{Na}$ opinião de Siqueira (2009), é nessa categoria que talvez se perceba mais nitidamente os discursos de sedução, fascinação e servidão voluntária. E, portanto, será a categoria mais enfocada durante esta pesquisa.

Espera-se de um indivíduo comprometido a sua fidelidade e dedicação acima de tudo. Logo, é por meio desse discurso ideológico que a empresa espera exercer controle sobre o corpo e a mente do trabalhador. "O discurso do comprometimento organizacional não passa de pano de fundo para que as empresas possam manipular e seduzir o indivíduo" (PABST; SIQUEIRA, 2008, p.382).

Todavia, é importante salientar o outro lado dessa realidade, que deve ser considerado pelas organizações. De acordo com Enriquez (2002), por mais que a empresa consiga a integração de seu pessoal e fazer com que ele aceite seus ideais, ela não pode provocar nada além da idealização. A idealização promove o fanatismo de empresa, porém não é capaz de criar nenhuma idéia nova. Ou seja, o fanatismo defende uma causa, mas não está apto à inovação. É importante que a empresa leve em consideração isso, pois, caso contrário, em vez de ter um grupo capaz de levar a empresa adiante, terá um que faz com que a empresa permaneça no mesmo patamar.

Diante dessa questão, e considerando que o processo criativo exclui as amarras racionais, é que as empresas procuram formas de fazer com que as 
pessoas engajem suas vidas no ambiente de trabalho. Não para o bem dos indivíduos, mas para o próprio lucro da empresa (ENRIQUEZ, 2002)

Esse fato traz à tona a questão do controle organizacional, assunto tratado na seção a seguir.

\subsection{Controle nas Organizações}

Desde o seu primórdio, o capitalismo busca dar ao trabalho alienado, juridicamente "livre", um significado de algo nobre, digno e, às vezes, até sagrado (ARAÚJO, 2008). Pretende-se, com isso, seduzir o trabalhador, para manipulá-lo conforme suas vontades. Ainda hoje é possível notar esse esforço nas empresas modernas que, "sob o argumento de reestruturação das relações de trabalho, começaram, então a fazer uso constante da manipulação da subjetividade do trabalhador, redirecionando as relações de trabalho e de dominação nas organizações" (PABST; SIQUEIRA, 2008, p. 379).

O objetivo disso é fazer com que a relação com o trabalho se torne a principal referência do indivíduo, cabendo às empresas a função de fornecer a identidade social e individual do trabalhador (FREITAS, 2002). Para o trabalhador, a empresa se torna o lugar ideal para alcançar seus objetivos, mesmo que, para isso, ele venha a perder a sua identidade e a orientação de sua vida. Em contrapartida, a organização espera que o indivíduo a ajude a alcançar suas metas (SIQUEIRA, 2007).

Além dessas transformações, as inúmeras mudanças que ocorreram no mundo do trabalho articuladas às características da pós-modernidade, também geraram uma nova lógica da racionalidade econômica que serve de inspiração para novas formas de organização do trabalho e que, conseqüentemente, criam novas formas de subjetivação, doenças, sofrimento e ação/reação dos trabalhadores (MENDES, 2007).

Surge então, nesse novo ambiente, a empresa gerencial, definida por Gaulejac (2007) como um sistema de dominação "sociopsíquico", em que se transforma a energia psíquica do indivíduo em força de trabalho. Cria-se um discurso, uma ideologia capaz de transformar o imaginário do indivíduo, o "local" 
onde está os desejos, sonhos e vontades, que é o ponto de partida de todas as significações (FREITAS, 2002). Dessa forma, a empresa consegue a adesão de seus funcionários e "esta adesão é um elemento fundamental para o poder da empresa e para o seu sistema de dominação e alienação dos indivíduos" (PAGES et al., 2008, p.75).

Com isso, de acordo com Gaulejac (2007), o objeto de controle da organização passa a ser a atividade mental e não mais a atividade física; substituise a repressão pela sedução, a imposição pela adesão, a obediência pelo reconhecimento. O objetivo é colocar o funcionamento organizacional e o funcionamento psíquico em sinergia para que o desempenho organizacional seja alcançado. Para isso:

A empresa oferece uma imagem de expansão e de poder ilimitado, na qual o indivíduo projeta seu próprio narcisismo. Tomado pela ilusão de seu próprio desejo, ele é animado pelo medo de fracassar, de perder o amor do objeto amado (aqui, a organização), o temor de não estar à altura, a humilhação de não ser reconhecido como um bom elemento. Ele é posto sob tensão, entre seu Ego e seu ideal, para o maior benefício da empresa (GAULEJAC, 2007, p.120).

Conseqüentemente, pode-se definir o poder gerencialista, caracterizado por uma gestão que enfatiza os objetivos financeiros, a mobilização psíquica e a produção da adesão; funcionando como um sistema de solicitação que gera um comportamento ideal capaz de por o projeto da empresa em prática (GAULEJAC, 2007). "Os tempos não são mais do chefe que comanda, mas daquele que seduz, persuade, exala charme, anima e sabe jogar com as aparências" (ENRIQUEZ, 2002, p.31).

Desta forma, o indivíduo passa a ser visto como um ativo e, portanto, deve adaptar-se às mudanças estabelecidas pelo capital, caso queira ser bem sucedido na organização (SIQUEIRA, 2007).

Essa empresa moderna oferece a possibilidade de sucesso, de realização
e, em troca, cobra a submissão do indivíduo ao seu discurso. Ao mesmo
tempo, o indivíduo se reconhece na organização, se identifica com seus
valores, aceita o imaginário organizacional como o seu e perde-se nas
"armadilhas" dos seus próprios desejos narcísicos, submetendo-se
voluntariamente à dinâmica organizacional e à insensatez do mundo do
trabalho (PABST; SIQUEIRA, 2008, p.378).

É acreditando nesse discurso, mesmo que de forma inconsciente, que o indivíduo se torna uma presa fácil para os interesses da empresa. De acordo com Gaulejac (2007), a partir do momento que o trabalhador projeta o seu ideal de ego 
sobre a empresa, seu compromisso se torna sem fim, enquanto o compromisso da organização permanece parcial, condicionando a manutenção do emprego ao desempenho de cada indivíduo.

Ainda de acordo com esse autor, como o indivíduo jamais conseguirá estar à altura dos desejos de desempenho da organização, ele se frustra e culpa a si próprio pelo fracasso e não ao sistema, que impõe isso (GAULEJAC, 2007). Com isso, a organização se isenta de culpa, cabendo ao próprio indivíduo corrigir seus defeitos e exigir cada vez mais de si mesmo um melhor desempenho. A realidade se distorce: não é a organização que exige isso, é a própria psique do indivíduo que cobra isso dele.

\begin{abstract}
Seu ideal de ego está sempre sedento e faminto, submetido a provas constantes e incapaz de se satisfazer, pois esse pódio não foi construído para ser pisado por humanos mortais. O indivíduo descobre a sua humanidade em seu desejo de ser esse herói, mas também em sua incompetência em fazer cumprir seu destino, do qual não é senhor e ainda não se fez Deus. O impedimento de cumprir esse papel foi selado na sua origem, pois o homem não foi desenhado para ser perfeito, muito menos para fazê-lo seguidamente (FREITAS, 2000, p.18).
\end{abstract}

Siqueira (2007) acrescenta que esse controle várias vezes é substituído pelo autocontrole, ou seja, os próprios indivíduos desejam melhorar sua produtividade e ritmo de trabalho. Para manter sua empregabilidade, o indivíduo é motivado a estar constantemente atualizado. Todavia, o ritmo de mudanças é tão acelerado que fica difícil acompanhá-lo. Com isso, esse processo de atualização acaba sendo permeado por um considerável nível de angústia, sofrimento e ansiedade (SIQUEIRA, 2009).

Segundo Mendes (2007), para conseguir evitar o adoecimento, por conta dessa dedicação sem limites, o trabalhador pode se alienar das causas do sofrimento; ou seja, não agindo sobre a organização do trabalho. Entretanto, essas formas de defesa de adaptação e exploração podem se esgotar facilmente, pois exigem do indivíduo um investimento físico e mental muito grande. Logo, a saída para este impasse está na (re) apropriação dos sujeitos-trabalhadores, isto é, no resgate do pensar e agir criticamente sobre a organização do trabalho e construir coletivamente soluções para se contraporem às contradições da própria organização do trabalho.

Como a organização "vai sempre manter uma face oculta nessa relação, de modo que nenhuma das duas partes tenha sempre consciência dos interesses e 
desejos da outra parte" (SIQUEIRA, 2007, p.5), é importante o indivíduo ter consciência dessa realidade para, assim, poder evitar as conseqüências negativas provocadas pelo excesso do trabalho. 


\section{MÉTODOS E TÉCNICAS DE PESQUISA}

Neste capítulo serão apresentados os procedimentos metodológicos selecionados para esta pesquisa. Além de caracterizar o tipo de pesquisa que foi realizada, é nesse momento que se definirá os participantes e apresentará o roteiro semi-estruturado das entrevistas. Por fim, tratar-se-á dos procedimentos de coleta e análise dos dados.

\subsection{Tipo e descrição geral da pesquisa}

A fim de alcançar os objetivos delimitados por esta pesquisa, foi realizado um estudo descritivo, utilizando uma abordagem crítica. De acordo com Richardson (2009), este estudo se aplica quando se tem a intenção de descrever as características de um fenômeno.

Ainda de acordo com este mesmo autor (2009), ao buscar uma análise mais detalhada daquela existente no senso comum, consegue-se descobrir as relações sociais e econômicas fundamentais para a existência de um fenômeno; justificando, assim, os benefícios de se trabalhar com a análise crítica.

\subsection{Caracterização da organização}

A empresa escolhida para realizar as entrevistas é uma multinacional asiática, que está no Brasil há dez anos. A fim de assegurar o anonimato dessa organização, será adotado o nome fictício "Empresa X".

A empresa $X$ atua no ramo de tecnologia no setor de telecomunicações. Ela oferece soluções para as principais operadoras de telefonia no Brasil e é líder de mercado em algumas frentes tecnológicas. 
A estrutura corporativa da empresa $X$ conta com mais de mil funcionários, distribuídos por seus três escritórios principais, localizados nas cidades de São Paulo, Rio de Janeiro e Brasília.

A empresa $X$ se encontra em um momento de expansão de seus negócios no país. Para manter esse crescimento, a empresa investe alto em pesquisa e desenvolvimento. Em 2008, além de ter atingido um faturamento de US\$ 1 bilhão, a empresa $X$ também foi reconhecida pela BusinessWeek como uma das companhias mais influentes do mundo. Tal marco comprova que o esforço da empresa $X$ não tem sido em vão.

Escolheu-se a empresa $\mathrm{X}$, pois, como toda empresa privada (e de porte internacional), existe um grande comprometimento com os resultados financeiros e, para que esses números sejam alcançados, é necessário o uso de um discurso que esteja alinhado com tal objetivo.

\subsection{Participantes do estudo}

Esta pesquisa se utilizou de uma amostra não probabilística. Isto é, os participantes foram escolhidos por determinados critérios intencionais. Como esta pesquisa procurou investigar de que forma o discurso organizacional afeta os indivíduos, buscou-se pessoas que atuam em áreas mais propensas ao controle organizacional, o que permite, conseqüentemente, uma análise mais crítica e detalhada da empresa pesquisada.

Para isso, foram entrevistadas seis pessoas que trabalham na área comercial da filial de Brasília. Isto é, profissionais que atuam na pré-venda ou pós-venda de produtos/serviços da empresa X. O perfil dos entrevistados está detalhado a seguir:

- Entrevistado 1: Participante do sexo feminino, solteira, idade entre 24 a 28 anos, com nível superior completo e pós-graduação. Atua na área de pósvenda e está na empresa há menos de dois anos.

- Entrevistado 2: Participante do sexo masculino, casado, idade entre 24 a 28 anos e com nível superior completo. Atua na área de pré-venda e está na empresa há menos de dois anos. 
- Entrevistado 3: Participante do sexo masculino, solteiro, idade entre 24 a 28 anos e com nível superior completo. Atua na área de pré-venda e está na empresa há mais de dois anos.

- Entrevistado 4: Participante do sexo masculino, casado, idade entre 28 a 34 anos e com nível superior completo. Atua na área de pós-venda e está na empresa há menos de dois anos.

- Entrevistado 5: Participante do sexo masculino, casado, idade entre 28 a 34 anos e com nível superior completo. Atua na área de pré-venda e está na empresa há menos de dois anos.

- Entrevistado 6: Participante do sexo masculino, solteiro, idade entre 28 a 34 anos e com nível superior completo e pós-graduação. Atua na área de pósvenda e está na empresa há menos de um ano.

\subsection{Caracterização do instrumento de pesquisa}

Conforme mencionado anteriormente, as entrevistas foram individuais e conduzidas pela pesquisadora, com base em um roteiro semi-estruturado, que está descrito integralmente no Apêndice deste estudo.

A seguir, apresentam-se, resumidamente, as questões tratadas no roteiro e o respectivo objetivo de cada uma.

A primeira questão tinha como objetivo conhecer o entrevistado e a sua trajetória profissional, procurando compreender o que o levou a ir trabalhar na empresa X.

Já com o próximo tópico, pretendia-se conhecer a opinião do entrevistado a respeito da empresa e de que forma ele enxergava a sua participação na construção e no desenvolvimento dela.

A terceira questão abordava sobre o ambiente de trabalho e a própria rotina das atividades, a fim de identificar possíveis frustrações/alegrias no discurso do entrevistado.

A pergunta seguinte tinha a intenção de saber se realmente a empresa oferecia possibilidades de carreira e qual o preço que o funcionário teria que "pagar", 
seja pessoalmente, seja profissionalmente, para conseguir ser bem-sucedido. Este tópico também avaliava a questão do comprometimento organizacional.

A quinta questão procurava investigar quais os mecanismos de controle que a organização utiliza para seduzir o funcionário ao favor do discurso organizacional.

A pergunta seguinte abordava sobre as metas. O seu objetivo era conhecer 0 esforço que o indivíduo e a organização fazem para alcançar o resultado esperado e se a empresa tinha alguma política de recompensa para esse esforço. Com esta questão também foi possível pegar percepções a respeito da motivação dos entrevistados.

Com o penúltimo tópico pretendia-se conhecer os métodos que a organização utiliza para conseguir o comprometimento organizacional e até que nível ela consegue ser bem-sucedida nisso.

Finalmente, a última questão procurava conhecer os planos futuros dos entrevistados - pessoal ou profissional - e descobrir se a empresa atual contribuía ou não para o alcance desses objetivos.

Este roteiro foi desenvolvido com base no modelo elaborado por Pabst (2008), para a sua dissertação de mestrado: "Discurso Organizacional como Manifestação de Poder: um estudo com executivos de empresas modernas". Posteriormente, este instrumento foi validado pelo Prof. Dr. Marcus Vinícius Soares Siqueira.

\subsection{Procedimentos de coleta e de análise de dados}

Os dados foram coletados pelo método qualitativo, pois é a forma mais adequada para conseguir compreender um fenômeno social (RICHARDSON, 2009). Esses dados foram obtidos por meio de uma entrevista semi-estruturada, que é usada principalmente para descobrir de que forma uma determinada experiência provoca mudança nas pessoas expostas a ela (RICHARDSON, 2009).

As entrevistas, individuais, ocorreram no local escolhido pelos entrevistados, em um horário propício determinado pelos próprios.

De acordo com Richardson: 
A melhor situação para participar na mente de outro ser humano é a interação face a face, pois tem o caráter, inquestionável, de proximidade entre as pessoas, que proporciona as melhores possibilidades de penetrar na mente, vida e definição dos indivíduos. Esse tipo de interação entre pessoas é um elemento fundamental na pesquisa em Ciências Sociais, que não é obtido satisfatoriamente, como já foi visto, no caso da aplicação de questionários (RICHARDSON, 2009, p. 207).

Ao início de cada entrevista foi explicado ao entrevistado o objetivo e a relevância da pesquisa, bem como a importância da sua cooperação. Também foi ratificada a confidencialidade dos dados informados e o anonimato do entrevistado. Além disso, foi solicitado a cada entrevistado que assinasse um termo autorizando a gravação de sua entrevista e o uso de suas falas a fim de exemplificar os resultados obtidos.

O objetivo do uso de gravador foi facilitar o processo de coleta de dados e, conseqüentemente, permitir que a pesquisadora pudesse fazer anotações adicionais sobre manifestações corporais e variações nas expressões orais dos entrevistados.

Após a transcrição das entrevistas, as informações passaram pelo processo de análise de conteúdo. De acordo com Bardin, esta análise é definida como:

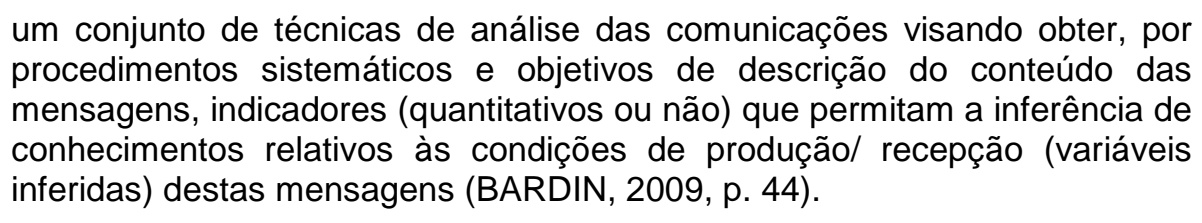

Com esses dados, foram identificadas as palavras idênticas, sinônimas ou próximas a nível semântico para, assim, realizar um agrupamento por classificação, definido como a "divisão das unidades significativas em categorias, rubricas ou classes" (BARDIN, 2009, p.54).

Para esta pesquisa, utilizou-se o sistema de categorias. Este sistema é válido quando se pode aplicá-lo com precisão a um conjunto de informação e quando é produtivo no sentido das inferências (BARDIN, 2009). 


\section{RESULTADOS E DISCUSSÃo}

A acumulação flexível do capital e a reestruturação produtiva dos últimos vinte anos geraram novas formas de organização do trabalho e essas, por sua vez, criam novas formas de subjetivação, de possibilidades de ação e reação dos trabalhadores.

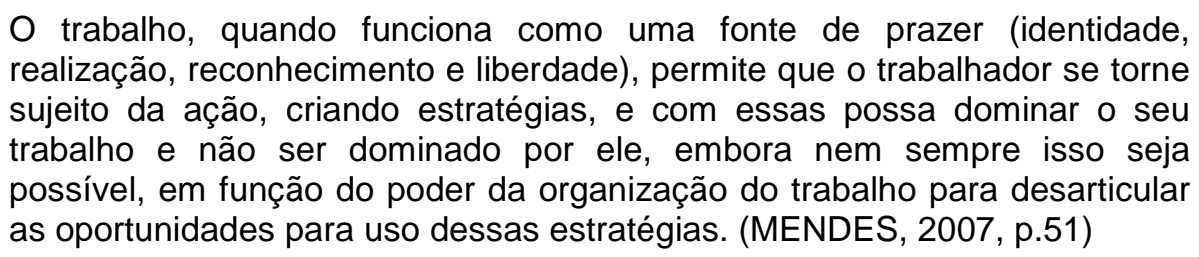

Neste capítulo de resultados e discussão da pesquisa será elucidado de que forma os funcionários percebem o discurso da empresa e como esse afeta suas vidas pessoal e profissional. Para tanto, utilizou-se a ferramenta de análise de conteúdo, já aludida anteriormente.

Nesta pesquisa foi possível agrupar os dados em seis categorias: o desafio cultural, as peculiaridades do ambiente de trabalho, a difícil rotina de trabalho, os mecanismos asiáticos de controle organizacional, comprometimento só até certo ponto e planejando o futuro.

Essas categorias se sobrepõem, em certos casos, da mesma forma que se complementam e, portanto, devem ser consideradas como mecanismos na compreensão dos resultados.

\section{Categoria 1: 0 desafio cultural}

Para os entrevistados, 0 fato da empresa $X$ ser asiática traz certas peculiaridades para o negócio. Do ponto de vista pessoal, foi considerado interessante trabalhar em um ambiente em que há uma cultura distinta da brasileira; inclusive para muitos isso é motivador. Entretanto, como precisam falar em inglês no dia-a-dia e este idioma não é a língua primária de nenhuma das partes, é comum haver falhas na comunicação. Quanto à prosperidade dos negócios, muitos viram a cultura como uma barreira para o sucesso da empresa no Brasil. Por não compreender a forma como os negócios no Brasil são feitos e o ritmo de trabalho dos brasileiros, a empresa cria uma série de barreiras para o seu próprio 
desenvolvimento, perdendo oportunidades de crescimento no país. Além disso, por ter uma forma de cobrança focada na punição, o clima organizacional é mais tenso, o que prejudica o relacionamento interpessoal entre brasileiros e estrangeiros.

Alguns temas citados que se enquadram nessa categoria foram: empresa asiática, cultura de negócios oriental, idioma distinto, lógica empresarial inflexível, conflito cultural, desconsideração do método brasileiro de fazer negócio, clima de desconfiança, barreira cultural, método de cobrança, tensão organizacional e medo da punição.

No Brasil [a cultura asiática] prejudica porque [...] a maneira que eles cobram é uma maneira mais para intimidar do que para motivar, [...] é uma cultura acostumada a punir. (entrevistado 1).

Eles acham que a parte de negociação no Brasil é igual à de lá. O que não é. Às vezes, até a gente tem muito problema para explicar como funciona [...]. Isso gera muito estresse. (entrevistado 3).

A cultura organizacional representa um sistema de valores compartilhados pelos membros que distingue uma organização das outras. Ou seja, pode ser definida como um conjunto de características-chave que é valorizado pela organização (ROBBINS, 2005).

No caso das empresas multinacionais, é comum que elas tragam para 0 novo país a cultura de seus países de origem, e a empresa $X$ não se difere nisso. Entretanto, o que é interessante observar é que a empresa $X$ possui algumas peculiaridades que a diferencia bastante das multinacionais americanas e européias.

Primeiramente, por ser uma empresa asiática, de cultura oriental, é esperado que haja certas dificuldades de adaptação em um país de cultura ocidental, não só para a empresa, mas também para os futuros funcionários. É importante mencionar também que essa diferença de cultura não se resume apenas a um idioma diferente, mas a uma série de costumes e valores que influenciam diretamente em aspectos referentes à liderança, à gestão de pessoas, à cobrança de resultados e ao próprio estilo de negócio da organização.

Uma segunda importante questão é que, ao contrário do que se observa na maioria das multinacionais instaladas no Brasil, na empresa $X$ há um grande número de estrangeiros trabalhando nas filiais brasileiras em cargos de baixo escalão e não só em cargos de liderança, como é o mais usual. 
Já trabalhei em outras empresas multinacionais, mas essa é diferente. Nas outras não tem um americano ou um europeu dentro da empresa no Brasil, [...] aqui têm vários. Isso gera um grande conflito cultural. (entrevistado 2).

Outro fato interessante é que, em vez de tentar se adaptar a cultura brasileira, a empresa $X$ procura implantar o seu estilo e a sua cultura no país. Tanto é que os funcionários brasileiros são mais vistos como contatos locais do que reais colaboradores da organização.

\begin{abstract}
A empresa poderia dar passos muito maiores por ano em termos de crescimento no país se tivesse a direção da empresa com brasileiros. Hoje existem diretores brasileiros, mas eles têm menos autonomia, [...] 0 brasileiro conhece o mercado e a própria cultura melhor e o estrangeiro vem querer implantar a cultura que ele trouxe de seu país. (entrevistado 2).
\end{abstract}

Frente a essa realidade, restam aos funcionários brasileiros duas alternativas: se adaptar a essa cultura ou procurar outro emprego. Por tudo que a empresa representa no mercado e pelo seu alto índice de crescimento, a grande maioria acaba optando pela primeira alternativa e procura ver a diferença cultural como um desafio positivo para sua carreira. Entretanto, bastam alguns meses na organização para perceber que a cultura realmente se torna uma barreira para os negócios e para os indivíduos brasileiros que ali trabalham.

Tem alguns pontos positivos, porque você tem noção de como funciona a cultura deles, você começa a entender um pouco do funcionamento da empresa, mas ao mesmo tempo eu sinto [...] que eles são contra as mudanças. Eles acham que o que eles aprenderam lá vale para o resto do mundo. (entrevistado 5).

Por estar mais habituado ao estilo ocidental de fazer negócios, é normal que os brasileiros tenham dificuldades para se adaptar ao estilo oriental. Entretanto, essa dificuldade não é apenas técnica, mas também é emocional, na medida em que afeta diretamente as expectativas e a motivação do indivíduo. A falta de reconhecimento, o foco na punição, a dificuldade de ascensão profissional, as metas absurdas, a desorganização dos processos, a falta de liberdade para tomar decisões, tudo contribui para tornar ainda mais difícil esse processo de adaptação.

Essa dificuldade de ajuste e a falta de flexibilização da cultura da empresa faz com que muitos funcionários se sintam frustrados e desmotivados com a empresa em menos de um ano, justificando a alta rotatividade.

Desta forma, pode-se dizer que os funcionários até se esforçam para se adaptar a cultura organizacional, mas por conta da falta de apoio, de motivação e das dificuldades da rotina de trabalho, poucos pretendem continuar nela por muito 
tempo e tal fato influencia diretamente no comprometimento desses indivíduos para com a organização, como será ilustrado pelas próximas categorias.

\section{Categoria 2: As peculiaridades do ambiente de trabalho}

O quadro de funcionários da empresa é formado por profissionais, em média, com menos de trinta anos de idade, o que torna o ambiente de trabalho de certa forma mais descontraído. Em contrapartida, o método de cobrança focado na punição, a desorganização de seus processos, as metas agressivas e a liderança estrangeira são pontos que trazem insatisfação e até mesmo desmotivação para alguns dos entrevistados. Outro fato que traz descontentamento é o próprio ambiente físico da empresa, definido como pequeno e barulhento.

Ao serem questionados sobre a imagem que a empresa $X$ tenta passar para as pessoas, seja para o candidato, seja para o funcionário, os entrevistados disseram que, no momento da entrevista de emprego, seus entrevistadores deixaram claro quais eram suas expectativas e não ocultaram as dificuldades que os futuros funcionários poderiam ter no cotidiano da empresa.

Exemplos de temas citados que se enquadram nessa categoria são: método de cobrança, desorganização, presença estrangeira, insegurança, ambiente de trabalho, idade dos funcionários, falta de mesa e a dificuldade de concentração.

Um ambiente de trabalho adequado, que ofereça os recursos necessários, é fundamental para que o trabalho possa ser realizado da melhor maneira possível. Além disso, um local de trabalho saudável contribui para a motivação dos funcionários.

Funcionários que acreditam estar recebendo tratamento justo também parecem mais motivados a 'ir além' no desempenho dos seus cargos. Alguns estudos sugerem que organizações grandes e centralizadas devem se esforçar mais para instituir procedimentos que façam o local de trabalho parecer justo para os funcionários (DESSLER, 2005, p.252).

$O$ ambiente da empresa $X$ pode ser analisado em duas partes: uma referente às pessoas e ao senso de justiça e outra referente à estrutura física e o estilo de negócio.

A respeito da primeira parte, os entrevistados estão satisfeitos. Gostam das pessoas com quem trabalham e acham que não há um clima de disputa na 
empresa. De acordo com eles também, o crescimento profissional se dá de forma ética e justa.

Eu gosto muito das pessoas, é motivador trabalhar com elas. (entrevistado 1).

É uma empresa que você pode crescer muito rápido se mostrar potencial, porém, para isso acontecer, você precisa estar bem relacionado dentro da empresa. (entrevistado 2)

[...] é uma empresa que tem algumas coisas interessantes como, por exemplo, uma média de idade bastante baixa. (entrevistado 5).

Você não precisa fazer nada ilegal para crescer, mas precisa se mostrar, procurar ser um diferencial. (entrevistado 6)

Já em relação à segunda parte, os entrevistados apresentaram algumas críticas. De acordo com eles, o espaço físico é insuficiente para o número de pessoas. Com isso, além da má acomodação, o barulho no escritório é bastante intenso e a falta de privacidade dificulta a concentração.

O meu maior choque quando entrei foi ver que eu não tinha mesa [...] já dividi mesa com mais dois. (entrevistado 4).

É bastante barulhento. É até difícil de concentrar às vezes. (entrevistado 6)

Além disso, a falta de confiança dos estrangeiros no trabalho dos brasileiros, o foco na punição e a pouca autonomia de decisão, como já mencionado anteriormente, contribuem para gerar um clima de tensão, mesmo que implícito, nos funcionários brasileiros. A desorganização dos processos e das informações também dificulta o desenrolar das atividades e geram um sentimento de insegurança nos profissionais, que ficam com medo de serem punidos por falhas da própria organização.

Registre tudo por e-mail porque algumas vezes você pode ter problemas por não ter tudo registrado. (entrevistado 1)

Eu apresentaria a empresa como sendo um pouco desorganizada [...]. Apresento também como uma empresa muito grande. (entrevistado 4).

Nas reuniões com cliente [eles] ficam com medo da maneira que vamos nos comportar, do que vamos falar, da maneira que vamos fazer certa atividade [...]. (entrevistado 1). 
Eles (funcionários estrangeiros) são muito desorganizados. Uma hora falam uma coisa e três dias depois ligam para avisar que estavam enganados. Então isso causa uma série de problemas, principalmente com o cliente, quando prometemos uma coisa que não conseguimos atender no final das contas. (entrevistado 3).

Considerando o ambiente de trabalho descrito pelos entrevistados, percebese que a empresa $X$ não procura propositalmente esconder suas dificuldades ou manipular a sua imagem. Por mais que ela não retrate fielmente o seu ambiente de trabalho para os candidatos, ela também não procura ocultá-lo. Ela deixa claro para seus candidatos quais serão os desafios e dificuldades, mesmo que em grau superficial. Para os entrevistados, essa atitude da empresa é bastante positiva, pois prepara os futuros funcionários para o trabalho, bem como nivela suas expectativas.

Falaram que é uma empresa grande (na entrevista para a vaga). E que vale a pena a pessoa entrar para ser um bom profissional, estar bem no mercado. (entrevistado 4).

A mensagem que o meu entrevistador passou foi que era uma grande oportunidade para mim. Que eu poderia usar como um trampolim, para chegar aonde eu quero, seja lá ou em outro lugar. (entrevistado 2).

O interessante do discurso adotado pela empresa $X$ é que, mesmo sendo de certa forma realista, ele ainda acaba seduzindo as pessoas. Essa sedução não é causada, em grande proporção, pelo que a diretoria defende e incita nos funcionários, mas sim causada pelo que a empresa representa no âmbito do mercado. Ou seja, o que seduz é o próprio tamanho da organização, seu grau de crescimento e a sua imagem no mercado. É um processo de sedução subliminar, mas que causa nas pessoas o interesse e a motivação para trabalhar na empresa, mesmo sabendo que o trabalho não será fácil.

Acho que qualquer pessoa se vislumbra por uma empresa bilíngüe, que preze o domínio de outras línguas, que a entrevista é em inglês [...]. (entrevistado 1).

$\mathrm{Na}$ empresa grande há mais chances de crescer do que em uma pequena. Não que a empresa $X$ seja uma empresa gigante para você crescer, mas é natural que lá haja mais oportunidades do que em uma pequena. (entrevistado 3).

O candidato, seduzido pelo desafio, pelo o que essa experiência irá contribuir para o seu currículo e futuro profissional, aceita essa oportunidade de braços abertos. E, ao entrar na empresa, vendo profissionais jovens ocupando 
postos cada vez mais altos, fica ainda mais entusiasmado com as possibilidades que poderão ser abertas a ele também.

A empresa não cria expectativa, é a própria pessoa que cria. Em nenhum momento a empresa te garante sucesso ou promete um cargo melhor. Isso tá implícito no ambiente, você vê gente jovem sendo chefe, a empresa crescendo, então conclui isso. Só que a gente não pensa que são poucos que conseguem isso. Então a gente trabalha e dá duro. Só que passa um tempo e a gente percebe que nada mudou. (entrevistado 1)

Para qualquer empresa é interessante que seus funcionários se sintam estimulados pelo ambiente de trabalho. Todavia, a empresa $X$ não demonstra muito interesse em construir e manter esse estímulo, na medida em que faz pouquíssimos esforços para cultivar esse entusiasmo em seus funcionários e proporcionar uma estrutura física adequada para a realização do trabalho.

Ela (empresa X) já parou com esse esforço (seduzir pessoas). Agora as pessoas querem entrar lá. Ela não precisa fazer mais nada. Se a pessoa está insatisfeita, que saia então. No outro dia já tem três tentando pegar a vaga dela. (entrevistado 4).

Com isso, vivenciando diariamente as dificuldades da empresa e percebendo que suas expectativas não foram atendidas como esperadas, logo o funcionário se desmotiva e, em uma questão de tempo, acaba pedindo demissão.

\section{Categoria 3: A difícil rotina de trabalho}

O ramo de telecomunicações tem um ritmo de trabalho bastante intenso e exige do profissional grande habilidade para trabalhar sob pressão. Além disso, o setor exige aprendizado constante e a formação/especialização em cursos técnicos (ou da área de tecnologia).

Por ser uma área que sofre muitas inovações, é necessário que os profissionais saibam lidar com as mudanças e se adaptem a elas muito rapidamente. A indisponibilidade de recursos, as falhas de comunicação e a desorganização interna da empresa só geram mais problemas e aumentam ainda mais o clima de tensão diário.

Esse setor também é conhecido por suas metas agressivas, que demandam muito esforço e estresse por parte dos funcionários, principalmente os da área de pré-venda.

A empresa $X$ funciona focada nas metas e estas são definidas pela matriz. Não há comissão ou bonificação individual para quem alcançar essas metas, mas há 
participação nos lucros e resultados para todos os funcionários, onde o índice varia conforme o seu desempenho.

Alguns temas citados que ilustram essa categoria são: correria, pressão, estresse, problemas com prazos, dificuldade de comunicação, muitos chefes, avaliação com foco nas metas, metas absurdas e a falta de poder.

"Cumpra as metas", acho que é a principal mensagem que vem de cima para baixo. (entrevistado 6)

Os níveis de avaliação são baseados nas metas. Vai de $A$ à $D$ se não me engano. Se a pessoa fica com D corre risco de ser demitida. [...] E a cada trimestre você é avaliado. (entrevistado 3).

Esse mercado de Telecom é um mercado que está sempre na correria, as coisas são sempre urgentes. É sempre aquela pressão para entregar rápido, fazer as coisas rápido, resolver e resolver. (entrevistado 4).

Entender as características da rotina de trabalho de uma organização é de extrema relevância para conseguir compreender o comportamento organizacional e individual, tendo em vista que essa rotina influencia diretamente na satisfação e motivação do indivíduo.

Na empresa $X$, a rotina de trabalho é bastante intensa, o que provoca uma série de desgastes, principalmente em longo prazo, nos funcionários. A falta de uma estrutura de trabalho adequada, a alta cobrança, a desorganização dos processos e das informações, dentre outras questões, só reforçam ainda mais o clima de estresse e ansiedade.

A rotina de trabalho é bem puxada, é bem trabalhosa, isso porque a gente está desenvolvendo um modelo novo e a empresa peca um pouco no sentido de prover a estrutura necessária para o alcance disso. (entrevistado 2).

É uma empresa bastante estressante do ponto de vista que às vezes você precisa se comunicar com uma pessoa que tem um idioma muito diferente do seu. (entrevistado 1).

Para Gaulejac, o estresse:

Distingue-se entre acontecimentos repentinos e perturbadores que têm um efeito por vezes traumatizante, mas esporádico, e situações permanentes, vividas cotidianamente, que são menos espetaculares, mas extremamente nocivas. O fenômeno é alarmante quando o estresse torna-se crônico. (GAULEJAC, 2007, p.220) 
De acordo com os entrevistados, a rotina de trabalho é vista como estressante porque, além de ter uma alta carga de trabalho, eles se sentem constantemente sobrecarregados e abandonados pela organização. Esta não lhes proporciona o apoio e a estrutura organizacional necessária para o cumprimento de suas atividades, exigindo, mesmo assim, que os resultados sejam totalmente alcançados.

Não é uma demanda que você pode cumprir em um horário normal, de oito horas. (entrevistado 1).

Uma coisa que é ruim na empresa é que lá você não tem um chefe direto, você tem alguns, então você não sabe quem realmente seguir, qual demanda deve dar prioridade. (entrevistado 6).

Esse clima constante de tensão e cobrança acaba gerando uma série de impactos negativos nos funcionários, o que, conseqüentemente, afeta seu desempenho e o da própria organização.

Até por causa da falta de ferramentas adequadas e a grande quantidade de demanda que a gente tem, faz com que o nosso trabalho caia em uma rotina ruim. Eu virei um grande fazedor de propostas, não tenho mais tempo para analisar, planejar as coisas. (entrevistado 5)

Você pode ficar doente com isso, porque a demanda é grande, é pesada, a cobrança é alta, você tem em suas mãos uma responsabilidade que envolve muito dinheiro, que envolve mercado. (entrevistado 4)

Para a empresa $X$, a preocupação com o bem-estar de seus funcionários brasileiros é quase que nula. Enquanto os resultados forem alcançados, ela não vê como necessário investir em políticas de qualidade de vida. O que a empresa não percebe (ou talvez por saber disso é que ela não age antes) é que ela, em geral, é uma das últimas instâncias a serem afetadas pelo estresse efetivamente. Antes de afetar seu desempenho na empresa de forma significativa, o estresse já atingiu a saúde física e mental do indivíduo, gerando impactos inclusive em sua vida pessoal. Quando passa a impactar de forma decisiva o seu desempenho no trabalho, então já está perto do chamado esgotamento profissional.

Para Gaulejac (2007), o esgotamento profissional é resultado do superinvestimento no trabalho e apresenta sintomas equivalentes ao da depressão. O termo inglês que o designa é chamado de burn out. 
O burn out sobrevém quando estamos nos esforçando demasiadamente para atingir um fim irrealizável. Somos consumidos a partir de dentro. $O$ aparelho psíquico fica então como um elástico demasiadamente esticado, como se não pudesse relaxar (GAULEJAC, 2007, p.218).

Por causa disso, acaba sendo responsabilidade do próprio funcionário zelar pelo seu bem-estar e procurar respeitar os seus limites, a fim de conseguir sobreviver a esta dura rotina.

Eu passei um pouco do limite, eu me desgastei muito, chegou a me afetar pessoalmente, [...] emagreci, comprometi minha alimentação, mas foi uma decisão minha, eu quis priorizar o trabalho. Quando consegui alcançar meu objetivo, as coisas ficaram mais tranqüilas. (entrevistado 1).

Antes o meu foco era só trabalho, agora estou tentando fazer um esporte, me alimentar melhor [...]. (entrevistado 4).

As metas, nesse contexto, têm uma influência decisiva. Como o foco da empresa $X$ são as metas, são elas que acabam permeando a rotina de trabalho. Não importa como as atividades são feitas, enquanto as metas estejam sendo alcançadas está tudo bem. O grande problema é que as metas da empresa $X$ não são facilmente atingidas e, muitas vezes, exige mais que competência e esforço do funcionário. Exigem que o próprio mercado (e os clientes) mude a sua postura.

\footnotetext{
Ela (empresa) espera que o nosso esforço seja convertido em números sempre, em vendas. (entrevista 6)

Existe muita pressão para alcançar as metas. A pressão deles (estrangeiros) é diferente, às vezes eles ofendem as pessoas. (entrevistado 1).
}

Deste ano (as metas) estão claras só que não sei de onde tiraram esses números [...]. (entrevistado 3 ).

Por não conseguir alcançar as metas, e diante da negação de sua vulnerabilidade, o indivíduo é constantemente pego em falha por insuficiência. Ele acha que a razão de não conseguir atingir os resultados esperados é causada por sua incapacidade e incompetência. Ou seja, ele se responsabiliza pelos defeitos da organização (DUJARIER apud GAULEJAC, 2007).

Entretanto, ao contrário do que é defendido pelos estudiosos da área, na empresa $\mathrm{X}$, em vez do funcionário se culpar por não ter conseguido atingir as metas, eles ficam frustrados com a própria empresa, pois sabem que esses números não foram estipulados de forma racional, mas sim levando em conta as vontades e os 
desejos numéricos da matriz. Ou seja, os funcionários têm a consciência de que se dedicaram o máximo possível dado as condições que tiveram. Para eles, o problema são os próprios números, que são inatingíveis.

Não são alcançadas (as metas), tem números extremamente absurdos. [...] na maioria das vezes são números irreais. (entrevista 2)

Não importa o quanto você trabalhe, o que importa é como você é medido. (entrevistado 3)

Com isso, eles vêem seus esforços como tendo sido em vão, criando um clima de desconforto e desmotivação. A empresa $X$ não tenta reverter esse sentimento e ainda expõe os funcionários que não alcançaram as metas, o que faz só piorar ainda mais esse clima de descontentamento.

$\mathrm{Na}$ próxima categoria, será discutido mais detalhadamente sobre essa política de punição e de que forma ela é percebida pelos funcionários.

\section{Categoria 4: Os mecanismos asiáticos de controle organizacional}

Por ser uma empresa asiática, a punição (ou ameaça dela) é a principal estratégia para manter os funcionários comprometidos com a organização. Desta forma, o controle organizacional surge no medo que os funcionários têm em ser punidos verbalmente ou pelo próprio medo da demissão. Entretanto, a empresa $X$ mostrou não ter um histórico de muitas demissões, fato contraditório ao seu discurso e postura perante seus funcionários.

Outra estratégia de controle organizacional é proveniente das facilidades tecnológicas. Se o tempo de trabalho se torna ilimitado, então convém poder trabalhar a qualquer momento e em qualquer lugar (GAULEJAC, 2007). Para isso, a empresa $X$ disponibiliza para cada um de seus funcionários um notebook e um celular, que deve permanecer ligado vinte e quatro horas por dia.

Além disso, a empresa tem uma estrutura enxuta de colaboradores, o que acaba gerando um grande fluxo de trabalho por pessoa. Com isso, o funcionário, mesmo sobrecarregado, se vê como fundamental para empresa, pois há uma grande quantidade de responsabilidade em suas mãos.

Os temas referentes a essa categoria foram: ameaça, injustiça, medo, possibilidade de demissão, repreensão verbal, foco nos erros, sobrecarga, 
importância para a empresa, excesso de demandas, controle excessivo, meios de comunicação móveis, flexibilidade e grande responsabilidade.

Se você não mantém um histórico de tudo o que você faz, quando der problema você pode ficar mal visto. Com isso, você perde promoção, pode ser demitido ou processado, retirado do projeto, receber pontuação negativa [...]. (entrevistado 1).

O bom do celular e do computador é que você pode resolver as coisas aonde quer que esteja. Não precisa ir ao escritório para isso. (entrevistado 3).

Aquele que não souber se explicar para a diretoria será acusado, aí acontece uma injustiça não por causa do trabalho em si, mas porque a pessoas não soube ser um bom advogado de defesa de si próprio. (entrevistado 4).

É a única empresa que você pode errar dez vezes e continuar lá. Eles põem muita pressão, fazem muito barulho [...], mas eles não tomam esse tipo de atitude de mandar embora fácil. (entrevistado 2).

O celular e o computador são estratégias para nos "encoleirar". (entrevistado 1).

É sabido que as organizações estão mais engajadas na sofisticação do controle de seus funcionários. No lugar do controle baseado na coerção, vem surgindo o controle pela gestão do afetivo. A fim de concretizar seus desejos, as empresas criam e utilizam qualquer modalidade de controle que possa aumentar suas chances de desenvolvimento em um mercado altamente competitivo (SIQUEIRA, 2009).

No caso da empresa $X$, ainda se percebe um esforço de controle pela coerção, apesar de que, indiretamente, se perceba mecanismos sutis para 0 controle do imaginário e do psiquismo do indivíduo. A modalidade de controle escolhida pela empresa $X$ é baseada principalmente no medo da punição.

Em conseqüência a esse discurso, cria-se um ambiente organizacional peculiar. As pessoas trabalham e se dedicam mais pelo medo de serem punidas, do que pela vontade de serem reconhecidas na empresa. Esse medo as motiva a se esforçarem, mas ao mesmo tempo gera um clima de insegurança no trabalho. fizer, será punido!” e não se fizer você vai ganhar. (entrevistado 1). 
Se você falha uma vez isso fica bem claro, bem exposto. É por isso que é importante se proteger porque a parte de punição, de caça às bruxas é muito presente quando acontecem os problemas. (entrevistado 4).

Por outro lado, a motivação também surge pela impressão dos funcionários acharem que são peças-chaves e fundamentais para a organização. A palavra "impressão" nesse momento é crucial, pois a empresa X não deixa claro essa idéia.

Eu cuido de muitas linhas de produto sozinho. Se eu sair agora o pessoal passará dificuldade. Não que eles não vão conseguir ir em frente, mas será difícil, pois tem muita coisa em minhas mãos hoje. (entrevistado 2).

Para os entrevistados, a forma com que ela reconhece um funcionário competente é através da delegação de atividades. Se o funcionário tem muitas responsabilidades é porque a empresa julgou que ele seria capaz de realizá-las, caso contrário, ela o demitiria ou o deixaria com poucas tarefas. Com isso, o excesso de demanda acaba funcionando como um reforço positivo para o profissional, apesar dos impactos negativos que isso possa vir a lhe trazer.

Em alguns momentos é motivador (ser o único responsável por uma demanda), dá a impressão que sou importante. Você precisar viajar para resolver as coisas, porque sem você não conseguem. Mas tem horas que essa responsabilidade é pesada. Às vezes não posso resolver o problema porque estou muito ocupado com uma outra coisa. Só que não tem outra pessoa para resolver. (entrevistado 3).

Para o funcionário, essa maior delegação de atividades é vista como uma possibilidade para que ele seja percebido na empresa como uma pessoa bemsucedida, imprescindível para o sucesso do negócio.

Isso motiva o indivíduo a se dedicar e a se sacrificar cada vez mais à organização, bem como para alcançar seus próprios objetivos (SIQUEIRA, 2009).

Neste contexto, é possível observar na empresa $X$ o perfil do superexecutivo de sucesso, categoria desenvolvida por Siqueira (2009) e já mencionada em capítulos anteriores.

Hoje eu tenho dado meu sangue pela empresa. (entrevistado 1).

Motivados a dar o seu máximo, os indivíduos ultrapassam os seus limites e colocam o trabalho em primeiro lugar; tudo em busca de serem reconhecidos como modelo de sucesso. Entretanto, quando o reconhecimento esperado não vem ou quando ele se resume apenas em mais responsabilidades, esse entusiasmo vai diminuindo, as dificuldades vão se tornando cada vez mais fortes e aparentes, até 
chegar ao ponto do indivíduo se sentir tão frustrado que realiza suas atividades com certo contra gosto, apenas na intenção de não ser demitido.

\section{Categoria 5: Comprometimento só até certo ponto}

Os entrevistados mostraram ter consciência que, para a empresa, são apenas um número e devem gerar resultados para garantir seus empregos. Entretanto, estão dispostos a se comprometerem até certo ponto, onde julgam ser o seu limite.

A razão desse comportamento se justifica, em muitos casos, pela falta de atenção que a empresa tem com o bem-estar de seus funcionários. Analisando a empresa X, notam-se poucos esforços da diretoria e da área de Recursos Humanos para motivar e reter os profissionais, o que acaba incentivando que estes não se comprometam o tanto quanto poderiam.

Os temas que caracterizam essa categoria são: carência de reconhecimento, inexistência de políticas de motivação, comprometimento moderado, alta rotatividade, aprendizado com experiências passadas, desmotivação, falta de atenção com o funcionário e dificuldade para reter talento.

Nós somos os números que fazem o escritório gerar números. (entrevistado 4).

Eu venho tentando mudar algumas coisas já tem um tempo. O cansaço chegou agora. Junto com o cansaço da rotina de trabalho tem essa frustração de não ver nada mudando. Isso tira nosso gás. (entrevistado 2).

Por mais que na teoria se saiba que as empresas enxergam seus funcionários como simples números, na prática não é fácil para nenhum indivíduo aceitar isso. Todos desejam ser necessários e imprescindíveis para a organização e a quebra desse imaginário pode ser cruel.

A gente não é tudo para empresa. Se sairmos amanhã, eles darão um jeito de colocar alguém no nosso lugar. Ela não vai parar porque estamos doentes. É triste isso, mas é a realidade. (entrevistado 6).

Como a empresa $X$ não estimula esse imaginário, é compreensível que a motivação e, conseqüentemente, o comprometimento organizacional sofram danos. Além disso, a falta de demonstração com o bem-estar dos funcionários é outro fator que limita o comprometimento organizacional. 
Eu não vejo muita preocupação da empresa com o meu bem-estar ou alimentação. Existem uns e-mails do $\mathrm{RH}$ só, mas não geram nenhum resultado. (entrevistado 2).

Vendo que a empresa não manifesta interesse ativo no funcionário, este acha que, por conseguinte, não precisa se comprometer tanto com a organização. $A$ dedicação exclusiva exige uma recompensa, nem que esta seja apenas intencional. A falta de interesse da empresa $X$ em investir em políticas de reconhecimento e recompensa acaba prejudicando, acima de tudo, ela mesma.

Se eu chegar para eles e falar: "Se der um bônus, uma premiação, todos vão ficar motivados e vão correr atrás para desenvolver o trabalho e melhorar." E eles vão responder: "Espera aí. Eu já pago o salário, eu ainda tenho que dar mais dinheiro para a pessoa fazer o seu trabalho? Isso é um absurdo!" Eles não vêem como um prêmio, vêem como aumentar o salário de graça, sem razão nenhuma. (entrevistado 5).

Conseqüentemente, a empresa cria uma ambiente de trabalho hostil, que incentiva o desinteresse e a desmotivação e, em um nível mais crítico, em demissões.

Eu venho tentando mudar algumas coisas já tem um tempo. O cansaço chegou agora. Junto com o cansaço da rotina de trabalho tem essa frustração de não ver nada mudando. Issso tira nosso gás. (entrevistado 2).

O grande desafio da empresa não é desenvolver o mercado, mas sim segurar os profissionais que desenvolvem esse mercado. (entrevistado 3 ).

O turnover na empresa foi sempre muito rápido, de seis meses a um ano. (entrevistado 6).

Há algumas semanas, o diretor do escritório veio falar comigo porque estava me achando muito quieto. A gente teve uma série de discussões, de reuniões que são extremamente desgastantes. Eles ficam querendo saber a opinião de todos, mas vira uma bagunça só e não dá em nada. Então eu cheguei em um estágio que eu não dou mais "pitaco", não dou mais minha opinião. (entrevistado 5).

Além das falhas na gestão das pessoas, a empresa $X$ também possui uma cultura organizacional e um ambiente de trabalho que dificultam a retenção de talentos.

A empresa $X$ falha nos três pilares fundamentais para reter os funcionários: ambiente de trabalho, retorno financeiro e perspectiva de crescimento. (entrevistado 5) 
Frente a essa realidade, pode-se concluir que, na empresa $\mathrm{X}$, a categoria do comprometimento organizacional (SIQUEIRA, 2009) é exemplificada parcialmente, na medida em que os objetivos e valores individuais não estão completamente alinhados com o da organização. Percebe-se um alto comprometimento nos novos funcionários, fato compreensível, já que o indivíduo está motivado e entusiasmado com os novos desafios e oportunidades. Entretanto, com o passar dos meses e frente a todas as dificuldades organizacionais já citadas anteriormente, esse comprometimento fica abalado.

\section{Categoria 6: Planejando o futuro}

A grande maioria dos entrevistados tem desejo de crescer profissionalmente, mas acham que esse crescimento não ocorrerá na empresa $X$, em virtude de algumas limitações da própria empresa.

Há ainda aqueles que gostam do que fazem e pretendem se manter no mesmo cargo, ou também aqueles que, por questões pessoais, pretendem mudar de ramo, construindo a carreira em um setor que seja possível conciliar seus interesses pessoais com os da organização.

Os temas que ilustram essa categoria são: comprometimento pessoal, estudo e aprendizado, trampolim na carreira, aproveitar as oportunidades, constituir família, crescimento profissional, novos desafios, estabilidade financeira, foco na carreira e plano de desenvolvimento pessoal. Para eu chegar aonde pretendo, preciso ter experiência com áreas
diferentes, porque quero estar em um cargo melhor [...] e para chegar nesse
cargo tenho que mostrar que já passei por muita coisa. (entrevistado 1).

Daqui a cinco anos eu tenho vontade de estar em uma posição melhor dentro da empresa, seja na empresa X ou em outra. (entrevistado 4).

Compreender a mensagem que está por trás dessa categoria é de suma importância para conseguir entender o comportamento dos profissionais no presente. A partir do momento que se conhece as aspirações futuras dos indivíduos, consegue-se avaliar mais criticamente a sua postura e suas atitudes atuais

Apesar de cada entrevistado ter pretensões distintas para o futuro, todos afirmaram ser pouco provável que estejam na empresa $X$ nos próximos cinco anos. As razões disso é que, além das falhas organizacionais, os entrevistados afirmaram 
que vêem poucas possibilidades de ascensão e de crescimento na empresa que estejam alinhadas com as suas próprias expectativas e interesses pessoais.

Daqui a cinco anos, me vejo fora da empresa. Em um concorrente que eu imagino ser mais bem estruturado e que compartilhe os mesmos ideais que eu. (entrevistado 2)

Quando questionados se a empresa X está contribuindo para levá-los aonde pretendem chegar no futuro, as opiniões dos entrevistados foram bem diversas.

A empresa $X$ não vai me ajudar muito a chegar aonde quero. Ela vai me colocar no caminho, mas não vai me levar até lá. (entrevistado 1).

O que eu tenho feito hoje sem sobra de dúvida me ajudará a chegar aonde quero; [...] se eu conseguir manter o ritmo, tiver sorte e surgir oportunidades boas, eu chego lá. (entrevistado 2).

Hoje eu estou acumulando conhecimento na empresa. Correndo mais atrás de experiência do que de dinheiro. Se fosse ao contrário, essa empresa não seria o melhor lugar. (entrevistado 4).

Não vai me ajudar diretamente. Quero trabalhar no setor público e o que aprendi na empresa me dá experiência de mercado, mas não me ajuda a passar em concurso. (entrevistado 6).

Queria pegar um cargo de gerência, mas estou longe disso ainda. Isso porque o que tenho feito hoje é mais braçal, o que inclusive me incomoda muito. (entrevistado 5).

Além dos planos profissionais, os entrevistados mostraram-se bastante focados em alcançar suas metas pessoais também. Inclusive, as aspirações de âmbito pessoal mostraram-se estar em coerência com os planos profissionais. De acordo com Robbins, os indivíduos sabem que o trabalho tem tomado cada vez mais espaço em suas vidas e, por estarem insatisfeitas com isso, procuram achar trabalhos que estejam alinhados com as suas necessidades e desejos pessoais. (ROBBINS, 2005).

A minha meta pessoal é alcançar a minha meta profissional. A empresa só se beneficia com isso. (entrevistado 1).

Eu quero casar e para isso preciso de dinheiro. Hoje não tenho essa condição. (entrevistado 3).

A preocupação do indivíduo com a sua vida pessoal é fundamental para a sua saúde física e psíquica, pois se ele não valorizar isso, não será a empresa que a 
fará. Ter ciência disso é fundamental para que o indivíduo possa ter uma postura mais ativa e conscientizada dentro e fora da empresa.

Por meio das categorias elaboradas anteriormente, e da discussão e interpretação de seus resultados, é possível compreender de que forma o discurso organizacional se caracteriza na empresa $X$, bem como as suas implicações na vida dos funcionários entrevistados.

Por conta de seus mecanismos de controle, a empresa $X$ consegue 0 comprometimento de seus profissionais, mesmo que de forma limitada. Além disso, a representatividade da empresa $X$ no mercado brasileiro e internacional mostrou-se como um importante fator motivacional para os funcionários, pelo menos em um primeiro momento.

Em consequência às características organzacionais da empresa $X$ e de seus esforços de controle, o ambiente de trabalho e a própria rotina de atividades se mostraram muito estressantes e desgastantes para os funcionários, gerando impactos na saúde física e mental destes. Por conta disso, e somada às inúmeras falhas organizacionais, a grande maioria dos entrevistados não se vêem na empresa nos próximos anos, seja por conta de ter interesses profissionais distintos aos da empresa, seja porque suas expectativas para com a empresa $\mathrm{X}$ não foram atingidas. Tal fato mostra que os entrevistados possuem certo nível de conscientização a respeito do que representam para a empresa e, por conta disso, conseguem avaliar de forma mais crítica o discurso organizacional e seus mecanismos de controle. 


\section{CONCLUSÕES E RECOMEDAÇÕES}

Para cumprir o objetivo principal da pesquisa, de identificar de que maneira os funcionários da empresa X são influenciados pelo seu discurso organizacional, fezse uma análise do que é pregado pela organização e qual é a percepção e reação dos funcionários a esse discurso. Para isso, utilizaram-se seis categorias que se complementam: o desafio cultural, as peculiaridades do ambiente de trabalho, a difícil rotina de trabalho, os mecanismos asiáticos de controle organizacional, comprometimento só até certo ponto e planejando o futuro.

$\mathrm{Na}$ primeira categoria destacou-se a questão da diversidade cultural, apontada como uma barreira para os negócios da empresa no Brasil, frente a sua dificuldade de adaptação e aceitação dos moldes culturais brasileiros.

Quanto à segunda categoria, pôde-se concluir que ela é decisiva para o clima organizacional, na medida em que afeta a maneira como os relacionamentos e os negócios se dão.

Em relação à terceira categoria, observou-se que a rotina de trabalho na empresa tem uma influência tanto positiva, quanto negativa na motivação dos funcionários. As metas agressivas e o foco quase que total nos resultados contribuem ainda mais para tornar essa rotina estressante.

$\mathrm{Na}$ quarta categoria, enfatizou-se os mecanismos de controle que a empresa utiliza no seu cotidiano, destacando a ameaça da punição como umas das principais ferramentas de controle organizacional adotadas pela empresa.

$\mathrm{Na}$ categoria seguinte, caracterizou-se o comprometimento dos indivíduos para com a organização. Notou-se que, por causa das falhas organizacionais e pela própria falta de atenção da diretoria, o comprometimento dos funcionários, de uma forma geral, é afetado negativamente.

A sexta, e última, categoria abordou sobre os planos futuros dos entrevistados, a fim de verificar se estes objetivos estavam alinhados com os da organização em que trabalham atualmente. Como resultado, descobriu-se que a grande maioria dos indivíduos não pretende continuar na empresa por muito tempo, visto que ela não atende às expectativas e aspirações profissionais e pessoais dos entrevistados. 
Este estudo contribuiu para desvelar as relações de poder que permeiam o discurso organizacional, que tentam instrumentalizar 0 indivíduo e justificar determinadas práticas organizacionais.

Os resultados da pesquisa demonstraram que os entrevistados possuem uma boa conscientização sobre o que representam para empresa e uma postura bastante ativa para defender seus desejos perante as imposições organizacionais dela, se sujeitando ao discurso até o ponto que consideram serem seus limites físicos e emocionais.

Percebeu-se que apesar de almejarem o sucesso profissional, a maioria não está disposta a pagar o preço para conseguir isto na empresa $\mathrm{X}$, preferindo buscar alternativas que trariam satisfação profissional e pessoal, simultaneamente.

Cabe ressaltar que, por ser uma empresa asiática, com um estilo de negócio oriental, a empresa $X$ tornou-se uma interessante empresa para esta pesquisa, na medida em que ilustrou uma cultura de negócio diferente daquelas exemplificadas nos estudos teóricos sobre discurso organizacional.

Desta forma, os objetivos específicos, de identificar as representações existentes no discurso da empresa e as representações dos próprios funcionários, de avaliar de que forma o discurso organizacional se insere na dinâmica do trabalho e de que forma os funcionários reagem aos esforços de sedução da organização, foram plenamente alcançados. Entretanto, novas questões surgiram, podendo ser sugeridas para estudos futuros.

Uma primeira sugestão diz respeito à empresa escolhida. Como a empresa pesquisada possui uma cultura oriental, seria interessante realizar esta pesquisa em uma multinacional ocidental, para verificar e comparar os resultados obtidos com os desta pesquisa.

Outra sugestão seria aplicar este roteiro semi-estruturado com executivos e diretores da empresa $X$, justamente para avaliar se o controle e os esforços de sedução da organização são diferentes para eles; e, no caso de o serem, de que forma esse controle organizacional se caracteriza.

Outra sugestão, que inclusive pode ser compreendida como limitação, seria a repetição das entrevistas, mas desta vez nas outras filiais da empresa no Brasil, bem como com um número maior de funcionários. O fato de se ter focado apenas na filial de Brasília e por este não ser o centro de negócios da empresa no país, pode ter gerado uma visão parcial de seu discurso e de sua estrutura organizacional. 
Finalmente, espera-se que esta pesquisa não só tenha acrescentado valor e interesse para os estudos da academia sobre essa temática, mas também que tenha proporcionado esclarecimentos e conscientização para os alunos de Administração e para os profissionais dos mais variados setores. 


\section{REFERÊNCIAS}

ARAUJO, J. N. G. Entre servidão e sedução: uma secular insistência do capital. In: MENDES, A.M.B. (Org.). Trabalho e saúde: o sujeito entre emancipação e servidão. 1‥Ed. Curitiba: Juruá, 2008, v. 1, p. 54-68.

BARDIN, L. Análise de conteúdo. Lisboa: Edições 70, 2009.

DESSLER, G. Administração de carreiras e tratamento justo. In:

Administração de Recursos Humanos. 2a . Ed. São Paulo: Prentice Hall, 2003. Cap.9.

ENRIQUEZ, E. O indivíduo preso na armadilha da estrutura estratégica. In: MOTTA, F.C.P.; FREITAS, M.E. (orgs). Vida psíquica e organização. $2^{\mathrm{a}}$. Ed. Rio de Janeiro: Editora FGV, 2002.

FARIA, J. H. (Org.). Análise crítica das teorias e práticas organizacionais. São Paulo: Atlas, 2007.

FREITAS, M.E. A questão do imaginário e a fronteira entre a cultura organizacional e a psicanálise. Em: MOTTA, F.C.P.; FREITAS, M.E. (Orgs). Vida psíquica e organização. 2ª . Ed. Rio de Janeiro: Editora FGV, 2002.

FREITAS, M.E. Contexto Social e Imaginário Organizacional Moderno. Revista de Administração de Empresas (FGV), São Paulo, v. 40, n. 2, p. 6-16, 2000.

GAULEJAC, V. Gestão como doença social: ideologia, poder gerencialista e fragmentação social. Aparecida, SP: Idéias \& Letras, 2007.

MENDES, A.M. Novas formas de organização do trabalho, ação dos trabalhadores e patologias sociais. In: MENDES, A.M (Org.) Psicodinâmica do trabalho: teoria, método e pesquisas. (p.50-60). São Paulo, SP: Casa do Psicólogo ®, 2007. (Coleção de trabalho humano / dirigida por Roberto Moraes Cruz)

PABST, F.R. Discurso organizacional como manifestação de poder: um estudo com executivos de empresas modernas. 2008. Dissertação (Mestrado em Administração) - Programa de Pós-graduação em Administração, Universidade de Brasília, Brasília, 2008. 
PABST, F.R.; SIQUEIRA, M.V.S. Discurso Organizacional como Manifestação de Poder: um estudo com executivos de empresas modernas. Revista Brasileira de Gestão de Negócios (São Paulo), v. 10, p. 376-390, 2008.

PAGES, M. et al. O poder das organizações. Tradução: Maria Cecília Pereira Tavares e Sonia Simas Favatti. São Paulo: Atlas, 2008

RICHARDSON, R. J. et al. Pesquisa Social. Métodos e Técnicas. 3á. Ed. - 10. reimpr.- São Paulo: Atlas, 2009

ROBBINS, S. P. O que é comportamento organizacional? In:

Comportamento Organizacional. 11a. Ed. São Paulo: Pearson Prentice Hall, 2005. Cap.1.

ROBBINS, S. P. Cultura Organizacional In: Comportamento

Organizacional. 11a. Ed. São Paulo: Pearson Prentice Hall, 2005. Cap.16.

SIQUEIRA, M.V.S. As artimanhas da gestão na realidade atual das organizações. Em: XI Colóquio Internacional de Psicossociologia e Sociologia Clínica. Belo Horizonte - MG, 2007.

SIQUEIRA, M. V. S. Gestão de pessoas e discurso organizacional: crítica à relação indivíduo-empresa nas organizações contemporâneas. 2ª . Ed. Curitiba: Juruá, 2009. 


\section{APÊNDICE}

\section{Apêndice A: Roteiro de Entrevista}

\section{Roteiro de Entrevista}

\section{Informações gerais sobre a entrevista}

Tema: Discurso Organizacional

Foco da entrevista: Conhecer a rotina e o perfil profissional do entrevistado.

Duração estimada da entrevista: 30 minutos a 1 hora, podendo ser mais se da vontade do entrevistado.

Protocolo de Pesquisa: Esta pesquisa tem fins acadêmicos e a análise dos seus dados é feita de forma agregada. Garante-se o anonimato e a confidencialidade dos dados fornecidos pelos entrevistados.

Autorização para o uso do gravador: Mediante a permissão do entrevistado, esta entrevista será gravada, para facilitar as análises de fins metodológicos.

\section{Dados do entrevistado}

Nome: № da Entrevista:

Sexo: Feminino ( ) Masculino ( ) Cargo:

Data:

\section{Entrevista}

1) Poderia, por favor, se apresentar e falar um pouco da sua trajetória profissional, desde o início da sua carreira até atualmente? Qual a sua história na empresa que trabalha hoje?

2) Como você apresentaria a organização a um amigo que foi recentemente contratado? Qual a missão da organização e como você contribui para a sua construção?

3) Em uma conversa informal com um amigo, como você descreveria as suas condições de trabalho/ rotina de trabalho? Quais seriam suas principais queixas (ao seu amigo)? Estas queixas poderiam ser discutidas na organização? Se sim, de que forma? Continuando a conversa com seu amigo, como você descreveria as expectativas da organização sobre seus colaboradores? Quem é responsável pela excelência no dia-a-dia? Você já se sentiu ou sente ainda como se tivesse que "matar um leão a cada dia"? Qual o sabor da vitória (na organização)? O que se conquista ao chegar lá no alto? É possível vencer com dignidade e ética? Qual o seu ideal de sucesso? Você acredita que a organização tem o mesmo ideal? Como você se sente fazendo parte de uma comunidade chamada "organização"?

4) Como as organizações modernas oferecem possibilidades de sucesso aos indivíduos? Qual a sua opinião sobre a realização do indivíduo na organização, da satisfação dos seus desejos e expectativas pela organização? Qual deve ser o limite de interferência das empresas na vida de seus colaboradores? Você considera que as empresas respeitam esse limite?

5) As grandes empresas utilizam-se de tecnologias gerenciais e modelos de gestão cada vez mais sofisticados, qual a sua percepção sobre a importância dessa "tecnologia" e sobre seus propósitos?A empresa te oferece alguma facilidade tecnológica (celular, notebook, etc.) para desempenhar seu trabalho? Existe alguma restrição/condição para o seu uso? 
6) Você conhece as metas e objetivos traçados pela organização para os próximos anos? Você participa destes resultados (i.e. você recebe benefícios quando os resultados são atingidos)? Como deve ser a participação dos funcionários na definição das estratégias das grandes empresas? Sua organização preocupa-se com o seu bem-estar, com exames médicos periódicos ou eventos sociais com a família, por exemplo?

7) Quais as práticas adotadas pelas empresas modernas para atrair e reter talentos? Qual a imagem que as empresas tentam transmitir aos candidatos? Pode-se dizer que a empresa moderna tenta seduzir e fascinar seus funcionários? Se sim, de que forma e com que propósito? A empresa consegue ser bem-sucedida nisso? Você acha que a empresa tem como objetivo essa submissão ou ela é apenas uma conseqüência indesejada?

8) De forma realista, aonde você espera estar daqui a cinco anos? O que você tem feito para conseguir concretizar os seus planos? Você acha que o que tem feito é suficiente? De que forma a empresa em que trabalha contribuirá para você chegar aonde deseja? 